\title{
Development of Interactive Mathematics Multimedia Teaching Materials for Building Space in Class V Primary Schools
}

\author{
Euis Gartika ${ }^{{ }^{*}}$, Wardani Rahayu ${ }^{1}$, Erry Utomo ${ }^{1}$ \\ ${ }_{1}^{1}$ Postgraduate of Basic Education, Universtas Negeri Jakarta, Jl. Rawamangun Muka, Jakarta Timur, 13220, Indonesia \\ gartikaeuis6@gmail.com, wardani9164@yahoo.com, erry30.utomo@gmail.com \\ ${ }^{*}$ Corresponding Author
}

How to Cite : Gartika, E., Rahayu, W., Utomo, E. (2019). Development of Interactive Mathematics Multimedia Teaching Materials for Building Space in Class V Primary Schools. International Journal for Educational and Vocational Studies, 1 (5), 467-472

\section{ARTICLE HISTORY}

Received: 11 June 2019

Revised: 21 July 2019

Accepted: 22 August 2019

\section{KEYWORDS}

Teaching Materials; Interactive Multimedia; Building Material

\begin{abstract}
This study aims to produce the development of interactive multimedia that is feasible to use in the mathematics of building space. The subjects of this study were in class $V$ of Panaragan 1 Elementary School in Bogor, Semplak 2 Elementary School, and Bogor 1 Police Public Elementary School. This interactive multimedia development uses a type of research and development concerning the model developed by Lee and Owens, there are 5 stages: assessment / analyze, instructional design, development, implementation, and evaluation. The media developed was validated by material and media experts before being tested on students. The instruments used to collect the data were 4.4 expert media feasibility test questionnaires, material expert questionnaire feasibility test 4.3 trial language feasibility expert 4.2 , declared feasible for use in learning.
\end{abstract}

This is an open access article under the CC-BY-SA license.

\section{INTRODUCTION}

In the world of education the use of technology is an effort to be creative and systematic in creating student learning experiences so that in the end it will produce quality graduates. Therefore, superior human resources must be prepared to improve the quality of education. The quality of future human resources can be determined by the quality of students now through a good learning process. Education in Primary School Learning in which the learning experience process takes place. During this time what happens in the learning process is only being a passive and fixated listener with teacher explanations without allowing students to develop their potential, and the role of teachers must choose the right model and media to carry out effective and efficient learning and the use of teaching materials which is interesting. Therefore the role of the teacher in utilizing the development of teaching materials must be following the needs of students and teachers so that learning objectives can be achieved properly.

Other data from the interview shows that mathematics learning is presented with pictures manually written on the board with the teaching material from limited source/ module books. So that the available media have not resolved students' difficulties in achieving mathematics learning competencies. Basically, the characteristics of elementary school students think concretely (Piaget, 2007), demonstrate themselves directly, enjoy playing (Mohd. Elmagzoub, 2015).

Mathematics is taught because it is needed and useful in daily life and functions as a means of communication through symbols and grammar (Hamzah and Masri, 2009). Mathematics lessons in schools use abstract symbols or symbols that are useful for manipulating established operating rules and assisting communication in understanding mathematical languages. Mathematics uses terms that are carefully defined, clear, and accurate, their representations with symbols that deal with ideas rather than sounds (Erman, 2001).

Building space is material in mathematics that is closely related to students' daily lives. The questions contained in this material are in the form of story questions which in their completion require deep conceptual experience. Teaching aids or media that are very much needed in helping to convey material to build space to maximize the senses of students play an active role in the learning process, to get a deep understanding of concepts for students.

The results of the assessment in the teacher questionnaire needs analysis can show data that teachers 
tend to use the lecture method. The results of the questionnaire analysis of student needs, there were $67 \%$ of students experiencing difficulties in learning mathematics. One hundred percent of students are interested in learning with interactive multimedia (CD) which is displayed in the form of videos that are equipped with images, sounds, music, and games.

Based on the results of data obtained by students and teachers very interested in using the development of interactive multimedia in the process of learning mathematics. Because the development of teaching materials is in the form of interactive multimedia which is very suitable to be applied because it can connect the knowledge obtained by students with everyday life to provide real knowledge. In this development, it will produce CD-based interactive multimedia teaching materials that are effective and efficient according to the needs of the school.

The use of interactive multimedia can facilitate teachers in delivering learning material. Multimedia is a combination of text, images, graphics, audio, video, and animation to integrate into a computer. In its use includes a combination of media components such as text, art, sound, and motion pictures (videos and animations) presented in computers (Annisa, Rudi, and M. Fachrudin 2017; Komalasari and Saripudin, 2017).

Some relevant results that have been done before reveal that in developing interactive multimedia can facilitate students on achieving the expected competencies. The results of Rusli and Rinathar's research reveal that learning using interactive multimedia can have a positive effect in improving student learning outcomes and motivation in learning (Rusli and Komang, 2017). Furthermore, Taufik's results that learning using interactive multimedia with a story based learning approach obtained an increase in learning outcomes in groups using interactive multimedia was higher (19\%) compared to groups that did not use (8\%) (Rangga, 2016).

Multimedia is defined as a noun and adverb. Multimedia nouns are to display material concepts visually and verbally while adverbs on learning activities in the form of images or words are presented in a structured manner to achieve a certain competency. "Multimedia fingers to a combination of several types of media such as text, graphics, animation, and motion video into a single computer application." Multimedia is a combination of two or more media such as/ audio, text, graphics, images, visuals, videos and animations, then in providing information is presented on other computers or electronics, which provide interactive processes, provide feedback, freedom in determining learning topics and easy to use (Muhammad Ali, 2009; Ministry of National Education, 2008; Stephanus, 2019).

Based on the background above, it is necessary to develop research, namely "developing interactive mathematics multimedia teaching materials for building space in the form of learning CDs" with research and development methods (Research and Development/Rn D.

\section{METHODS}

The method that will be used in this research is research and development $(\mathrm{RnD})$. The development method is one of the developmenst of research that focuses on the development and validity of innovative and effective products for an achievement (Meredith, 2007). The research model that will be used in this study is the Lee and Owens model/ because this model is a very relevant and very appropriate model for development that uses to design the development of interactive multimedia products. Lee and Owens, there are five stages used to developmultimedia products, namely: assessment/analyze, instructional design, development, implementation, and evaluation (William and Diana, 2004). Based on the methods and procedures in this study derived from data from questionnaire data, interviews, and observations.

\subsection{Questionnaire}

Questionnaires with the Likert scale are guidelines used to carry out questionnaire results data on the research conducted. The questionnaire distributed to experts was presented in a closed questionnaire to save costs in accelerating implementation time (M. Aziz, 2012). The data analyzed include/assessment and analysis of needs and data from expert review validation results. The results of the questionnaire results are calculated using the standard Likert scale with the value interval as shown in Table 1.

Table 1. Likert Scale

\begin{tabular}{cc}
\hline Value & Definition \\
\hline 5 & Very good / very agree \\
\hline 4 & Good / agree \\
\hline 3 & Poor / disagreeable \\
\hline 2 & Not good / disagree \\
\hline 1 & Strongly disagree / strongly disagree \\
\hline
\end{tabular}

Source: M.Aziz Firdaus, Research Method, p.67.

The interval scale obtained from each aspect will then be informed as a percentage using the following equation: With information:

Percentage $=\sum$

$\sum=$ amount

$\mathrm{n}=$ number of values obtained as a whole

$100 \%$ = fixed number

When the percentage results are obtained, the results are categorized into the interpretation of the percentage of success as presented in table 2 . 
Table 2. Interpretation of Percentage of Success

\begin{tabular}{cc}
\hline Value & Interpretation \\
\hline $81-100 \%$ & Very good \\
\hline $6-80 \%$ & Good \\
\hline $41-60 \%$ & Medium \\
\hline $21-40 \%$ & Low \\
\hline $0-20 \%$ & Very Low \\
\hline
\end{tabular}

Source: Iskandar, Social Education Research Methodology

The criteria for the success of the interactive multimedia products developed will be used in test items, content, and face validity. These criteria must meet a minimum percentage of $70 \%$ ( $70 \%$ of the validator gives his approval of each aspect that is an indicator of assessment) then analyzed in the form of qualitative data presentation. When validated products obtain the minimum success criteria, the development carried out has succeeded in meeting the standards and the product is ready to be implemented, but when the product has not obtained the minimum success criteria, revisions are carried out to reach the minimum success limit.

\subsection{Interview}

Data that has been collected based on the results of the interview will be processed based on the problems that will be answered to make a conclusion. Because in this interview it was done to the teacher by using structured interview guidelines and can be revealed some information related to supporting data to get the multimedia products needed at the assessment stage and the results of the needs analysis.

\subsection{Observation}

Everything collected through observation (taking photos or videos) shows some information to complete the data at the stage of assessment and needs analysis. The findings are then analyzed and processed as supporting data for the discovery of multimedia products that will be needed.

\section{RESULTS AND DISCUSSION}

The purpose of this product development research is to know the learning conditions in class $\mathrm{V}$ of elementary school. The procedure for developing interactive multimedia learning mathematics refers to the stages of research and developing the Lee and Owens model. In the analysis, phase defines the conditions needed in learning. This initial stage is in student analysis, concept analysis, and learning objectives. The research was carried out by observing at Semplak 2 Bogor Elementary School, Bogor Panaragan 1 Elementary School, and Bogor Police 1 State School.
Based on the results of the observation, Panaragan 1 Elementary School has a complete computer lab information technology equipped with computer devices. the completeness of the facilities owned by the school has not been used optimally for all relevant learning activities. The results of other interviews that are one of the needs analysis data show that the learning media used in mathematics learning are presented in the form of manual images written on a limited basis from information sources/modules that provide them. computer labs and all equipment used for computer learning (ICT), Practice exams, administration, and extracurricular activities.

At the stage of assessment and needs analysis, students are involved in finding learning products needed by filling out questionnaires. The questionnaire results that have been filled out by students show the data as shown in Figure 1.
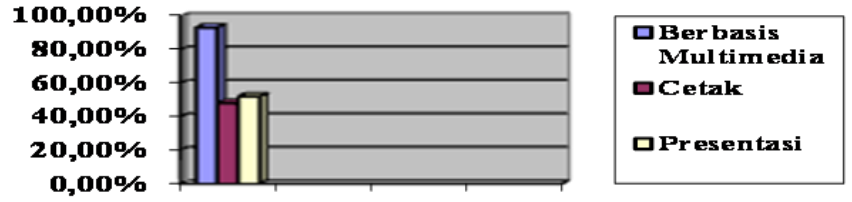

Figure 1. shows that the building material for $\mathrm{d}$ class V space is very difficult. The opinions of students proved to be a percentage of $50.89 \%$, greater than the multiplication material of $28.75 \%$, and the distribution material was $38.56 \%$.

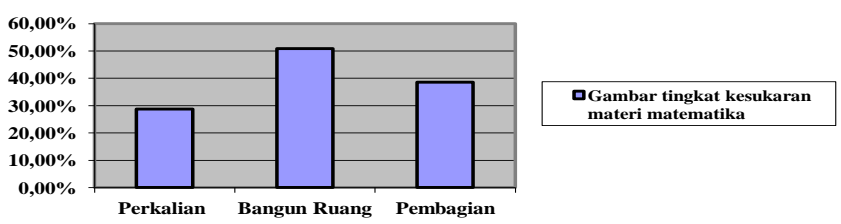

Figure 2. percentage tendency of students to choose media

Figure 2 explains that students are very interested in computer-based media (multimedia). This is further evidenced by the acquisition of the percentage obtained based on student outcomes for multimedia at $93.25 \%$ greater than the print media of $48.22 \%$ and the percentage of media by $51 \%$.

The Planning (design) stage includes a series of activities such as making a schedule in multimedia development. At this stage also includes activities to design media specifications that will be developed and design the material structure to be developed in multimedia. Development also prepares the tools needed in the expert validation process and student trials.

The product development stage is to translate product specifications into physical forms, interactive media software. This development phase includes making storyboards. This storyboard serves as a guideline for development in material input, developing interface designs that will be used in interactive multimedia 
products. Developing the presentation of the content presented in multimedia services, conducting reviews or repairs that are needed so that the product is deemed feasible to be implemented in the learning process and finally the product packaging on CD (Compact dist).

The implementation phase is validated by media experts and material experts. After the product is declared by the expert, it is then tested on students. This implementation phase includes a series of student pilot activities consisting of individual group trials, small group trials, and large group trials. Small group trial activities and large group trials involve students as the subject of the trial. Small group trials involve a sample of students taken based on the level of understanding of the material or learning outcomes achieved through value data from the class teacher. Large group trials involve students in one class, but students who have taken small group trials do not take part in large group trials.

The evaluation phase, in this development, evaluates interactive multimedia products. The evaluation carried out in this development research was an evaluation oriented to the validity of multimedia which was developed through the validation of media experts, material experts and the results of product trials. This evaluation phase is related to the previous stage, namely the fourth stage. The evaluation phase is carried out after each series of activities in the fourth stage (expert validation and product testing) is carried out in the evaluation phase based on the results of validation and product testing.

The feasibility of this media uses two stages, namely theoretical validity carried out by experts and empirical validity by students. Toitic validity serves to determine the feasibility of learning products that are developed based on assessments obtained from expert evaluations. Experts who assess this learning multimedia product are among the media experts by Dr. Murni Winarsih, M.Pd Lecturer in Basic Education at Jakarta State University, material expert by Dr. Arifin Maksum, M.Pd Lecturer at PGSD at Jakarta State University, linguist lecturer by Prof. Dr. Zulela MS, M.Pd, Lecturer in Basic Education, Jakarta State University. This expert evaluation is the first feasibility test conducted to improve the product so that it can be tested in the next stage. Data obtained from validity by experts will be analyzed by average analysis techniques. From the average value then the level of feasibility of the learning media is developed. The formula for calculating the average value is as follows:

$$
\mathrm{X}=\frac{\sum \mathrm{x}}{\mathrm{n}}
$$

Note: $\mathrm{X}=$ average value

$$
\begin{aligned}
\sum \mathrm{x} & =\text { total score of the respondent's answer } \\
\mathrm{n} & =\text { number of assessors }
\end{aligned}
$$

Development of this device will be used adobe flash CS 6. the need to be needed in supporting the making of this learning media, namely: a. Hardware requirements, AMD
Quad-Core Processor, Random Access Memory, Hard Disk, Keyboard and Mouse. b. Software requirements are adobe Flash CS6, CorelDraw X4, and Adobe Photoshop CS6. The application user interface is as follows:

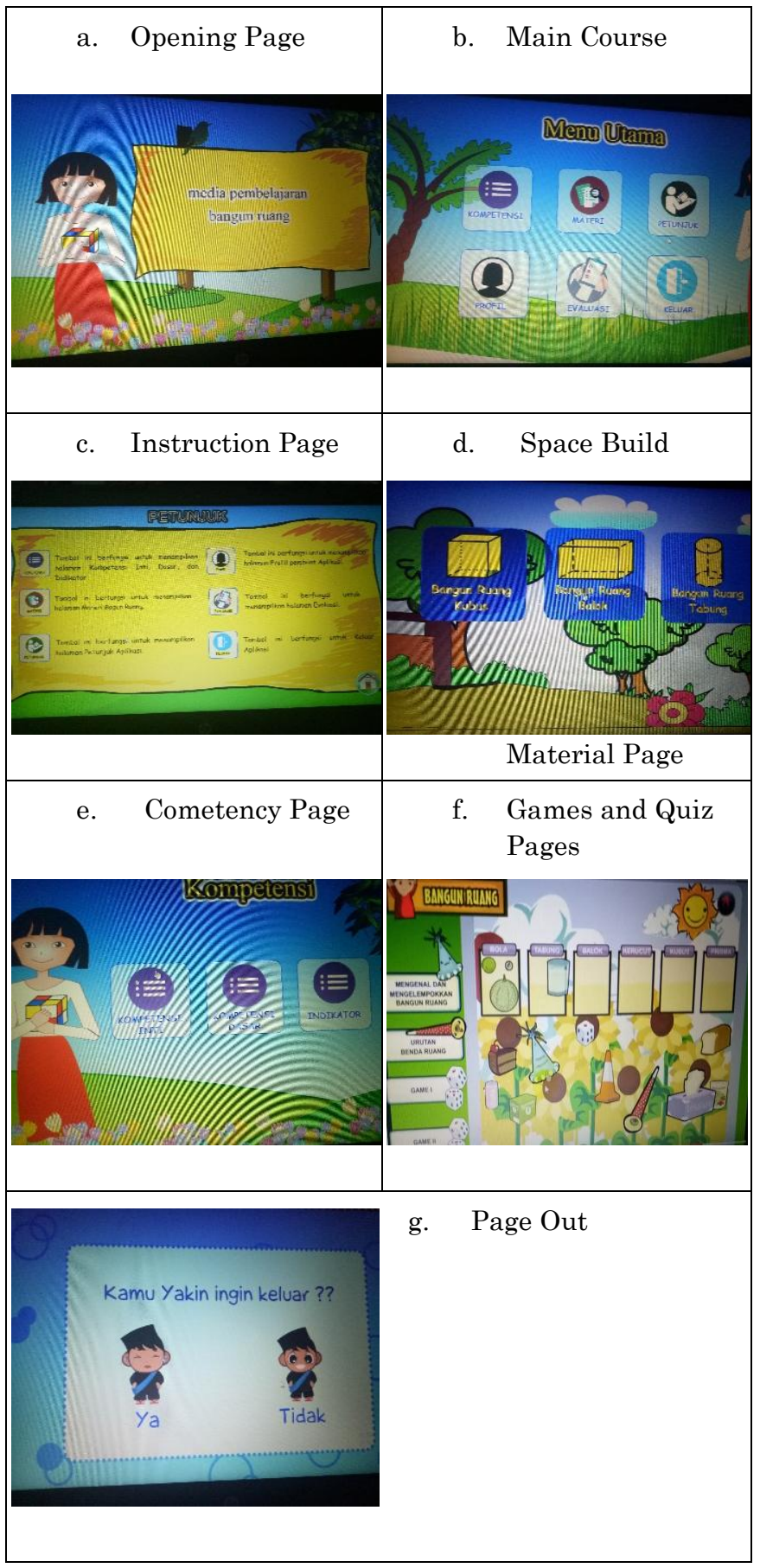

The results of the assessment by media experts get an average value of 3 . The following are the results of evaluations by media experts:

Table 3. Assessment by Media Experts

\begin{tabular}{clc}
\hline No & Aspects assessed & Average \\
\hline 1 & Display image & 4 \\
\hline 2 & Use of sound and text & 5 \\
\hline 3 & Use button & 4 \\
\hline
\end{tabular}




\begin{tabular}{cll}
\hline 4 & Slide transfer & 4 \\
\hline 5 & Suitability of type and size of front & 4 \\
\hline 6 & Color selection & 5 \\
\hline 7 & Screen display & 5 \\
\hline 8 & Effectiveness and efficiency & 4 \\
\hline 9 & Kemenarikan media & 5 \\
\hline 10 & Instructions for use & 4 \\
\hline 11 & Opening & 4 \\
\hline 12 & Transition & 4 \\
\hline 13 & Closing & 4 \\
\hline & Media Expert Test Score & 4.3 \\
\hline
\end{tabular}

The results of the validation from the media experts obtained quantitative data that showed that the learning media in the feasibility aspect, the media was in the proper criteria (4.3).

The results of the assessment by material experts get an average value of 4.4. The following are the results of the assessment by material experts:

Table 4. Assessment by Material Experts

\begin{tabular}{clc}
\hline No & Aspects assessed & Average \\
\hline 1 & $\begin{array}{l}\text { Conformity with core Competencies (KI) and } \\
\text { Basic Competencies (KD) }\end{array}$ & 5 \\
\hline 2 & Conformity with learning objectives & 5 \\
\hline 3 & Clarity of material description & 5 \\
\hline 4 & Understanding of material & 4 \\
\hline 5 & Practice/evaluation questions & 4 \\
\hline 6 & Systematic presentation of material & 5 \\
\hline 7 & Suitability of animation/image & 4 \\
\hline 8 & Suitability of examples and exercises & 4 \\
\hline 9 & Students can study independently & 4 \\
\hline 10 & Use of symbol & 4 \\
\hline 11 & Accurate use of letter & 4.4 \\
\hline 12 & $\begin{array}{l}\text { Clarity of instructions for working on the } \\
\text { questions / tests prepared }\end{array}$ & 4 \\
\hline & Material Expert Test Score & 4 \\
\hline & & 4
\end{tabular}

The results of the validation from the media experts obtained quantitative data which showed that the learning media in the feasibility aspect, the media was in the proper criteria $(4,4)$.

The results of the assessment of linguists get an average value of 4 The following are the results of the assessment by material experts:

Table 5. Assessment by Linguists

\begin{tabular}{clc}
\hline No & \multicolumn{1}{c}{ Aspects assessed } & Average \\
\hline 1 & Simplicity Directions & 4 \\
\hline 2 & politeness to use language & 4 \\
\hline 3 & Sentence Accuracy & 5 \\
\hline 4 & Conformity to the use of punctuation & 4 \\
\hline 5 & Suitability of spelling use & 4 \\
\hline & Score Language Expert & 4.2 \\
\hline
\end{tabular}

Validation results from linguists obtained quantitative data which showed that the learning media in the feasibility aspect, the media was in the proper criteria (4.4).

Learning media is a messenger technology that can be used for learning purposes from the results of this study, that the learning media of interactive multimedia teaching materials are feasible for use in learning.

Empirical validation was carried out after the theoretical validity with the one-on-one testing stage was conducted on 6 students of class V of SDN Panaragan 1 as interactive multimedia users with one to one researchers to do the knowledge of interactive multimedia practices. Students were randomly selected to represent the three target populations, namely participants with low, moderate, and high abilities.

The stages of the Small Group Try-Out at this stage of the media have been revised based on input from one-on-one evaluations, the researchers tried interactive multimedia in a group of students in class V, totaling 10 students from SDN Panaragan 1. Large group trials (Field Try-Out) At this stage the final media is based on input from one-on-one evaluations and small group evaluations, the researchers try interactive multimedia in students in class V, amounting to 30 students from Panaragan 1 Elementary School.

This interactive multimedia development is not carried out destination or dissemination so it is not necessary to have effectiveness through the t-test. But the development carried out pretest and posttest for 30 students during the field test or Try-Out field. The trial was carried out by 30 students and through the first few steps students were given a pretest, before giving an explaining of interactive multimedia learning in building materials, students who took the pretest got an average score of 50.46 out of 100 which was the maximum value. In this presentation, it is categorized as low and it has been proven that students in Panaragan 1 Elementary School need help in interactive multimedia materials to build space. After working on the pretest, students get a score of 7.00 out of 100 . After students are given an explained of the material of building space using a computer. 


\section{CONCLUSION}

Some things can be concluded based on the results of the research that has been obtained relating to the development of interactive multimedia mathematics learning material in the building of students of elementary school class $\mathrm{v}$ as follows:

The interactive multimedia developed was deemed feasible by three experts (material, media, and language) and students in a large group test so that it was effectively implemented in the mathematics learning process of students in grade v Elementary School.

Interactive multimedia learning mathematics that was developed effectively in improving the learning outcomes of mathematics in building materials for the fifth-grade students of elementary school.

\section{REFERENCES}

Annisa Alkarimah, Rusdi, M. Fachruddin. (2017). Efektifitas Pembelajaran Matematika Menggunakan sofware Animasi Berbasis Multimedia Interaktif Model Tutorial Paa materi Garis dan Sudut Untuk SMP Kelas VII, Jurnal Penelitian Pembelajaran Matematika Sekolah (JP2MS) Vo. 1, No. 1 ISSN 2581-253X ( 3 Maret 2009 ).

Depdiknas. (2006). Undang-Undang Guru dan Dosen UU RI No.14 Th. 2005 dan Undang-Undang Sisdiknas (Sistem Pendidikan Nasional) UU RI No. 20, Jakarta: Asa Mandiri.

Erick Burhaeni. (2016). Aktifitas Fisik Olahraga Untuk Pertumbuhan dan Perkembangan Siswa SD, Journal Of Primary Education, Vol. 1 No. 1 (3 Maret 2009).p 51-56

Erman Suherman. (2001). Strategi Pembelajaran Matematika Kontemporer, Bandung : JICA-UPI.

Komalasari dan Saripudin Didin. (2017). Value-Based Interactive Multimedia Development Through Integrated Practice For The Formation Of Student's Character,ed.2017 volume 16 nomor 4, The Turkish Online Journal of Education and Technology, http:// files. Eric.ed.gov/fulltext/ Ej160605. Pdf (diakses 6 september 2018).

M. Aziz Firdaus. (2012). Metode Penelitian. Tanggerang: Jelajah Nusa. Hal.67

Meredith D. Gall, Joy P. Gall dan Walter R. Borg. (2007). Educational Research an Introdution Seventh Edition,New York: Longman.

Mohd. Elmagzoub A. Babiker. (2015). For Effective Use of Multimedia in Education, Teachers Must Develop their Own Educational Multimedia Applications, ed. October 2015 Volume 14 Nomor 4, in the TOJET: The Turkish Online Journal of Educational Technology, http://files.eric.ed.gov/fulltext/EJ1077625.pdf
Muhamad Ali. (2018). "Multimedia Based On Scientific Approach For Periodic System Of Element" Jurnal Materials science sng Engineering @Elektro Vol 5, No1 (25 September 2018).

Muhammad Rusli dan Komang Rinathar. (2017). The Effect Animation In Multimedia Computer-Based Learning and Learning Style to The Learning Results,ed. Volume 18 Nomor 4, Turkish Online Journal Of Distance Education-Tojde, http://tojde. Anadolu.edu.tr/.EJ1161807.Pdf (diakses 6 September 2018).

Piaget, Jean \& Barbel Inhelder.(2007). Psikologi Anak. (Penerjemah:Miftahul Jannah). Yogyakarta:Pustaka Pelajar.

Hamzah B. Uno dan Masri Kuadrat. (2009). Mengelola kecerdasan Dalam Pembelajaran , Jakarta: Bumi aksara.

Rangga Sanjaya. (2016). Multimedia Interaktif Pelatihan Service Excelent Menggunakan Pendekatan Story Based Learning, Volume 3 Nomor 1 ,

http://ejournal.bsi.ac.id/index/.php/ji/article/view/302 /295. (diakses 6 September 2018).

Stephanus Turibius Rahmat. (2019). Pemanfaatan Multimedia Interaktif Berbasis Komputer Dalam Pembelajaran. Jurnal Pendidikan dan Kebudayaan Missio Vol 7, No. 2. Hal. 7.

Taufiq Nuril Akbar, Pengembangan Multimedia Interaktif IPA Berorientasi Gulded Inquiry Pada Materi Sistem Pernapasan Manusia Kelas V SDN Kebonsuri 3 Malang, ed. Juni 2016 Volume 1 Nomor 6, di dalam Jurnal Pendidikan: Teori, Penelitian, dan

Pengembangan,hhtp://Journal.um.ac.id/index.php/jp tpp/article/view/6456/2737(diakses Mei 2019)

William W. Lee dan Diana L. Owens. (2004). Multimedia-Based Instructional Design: Computer-Based Training, Web-Based Training, Distance Broadcast Training, Performance-Based Solutions Second Edition (San Fransisco: Pfeiffer), h.112. 